Acta Protozool. (2020) 59: 121-139 www.ejournals.eu/Acta-Protozoologica doi:10.4467/16890027AP.20.010.13265

PROTOZOOLOGICA

\title{
Taxonomic Revision and Classification of Extant Holococcolithophores Previously Placed in the Genus Anthosphaera Kamptner emend. Kleijne 1991
}

urn:lsid:zoobank.org:pub:0E5D4BD7-BC3B-4D30-B319-964AC887DDDE

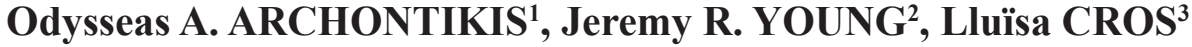 \\ ${ }^{1}$ Department of Earth Sciences, University of Oxford, Oxford, UK \\ ${ }^{2}$ Department of Earth Sciences, University College London, London, UK \\ ${ }^{3}$ Institut de Ciències del Mar, CSIC, Barcelona, Spain
}

\begin{abstract}
The genus Anthosphaera Kamptner emend. Kleijne is one of the most taxonomically confusing modern coccolithophores and its species level taxonomy has long been in a state of flux. Based on the review of imaged specimens from our collections, we attempt to rectify the nomenclatural problems and elucidate the obfuscated taxonomy of the genus. Review of included formally and informally described species shows that they are a distinctive group with shared characters, including ten different morphotypes of probable species level. Two of these, including the type species A. fragaria, have been shown to form life-cycle associations with heterococcoliths of the Syracosphaera molischii type. Hence, all species are transferred to Syracosphaera and the new combinations S. periperforata, S. lafourcadii, and S. origami are proposed. In addition, various informally described morphotypes are now formally described as Syracosphaera molischii var. pertusa, S. periperforata var. cylindrata, S. periperforata var. tridentata, S. rotaconica, and S. elevata.
\end{abstract}

Keywords: Coccolithophores, extant, Anthosphaera, Syracosphaera, holococcolith, taxonomy, biodiversity, fragariolith.

\section{INTRODUCTION}

Coccolithophores are unicellular phytoplanktonic algae of the Phylum Haptophyta that produce intricate plates of calcium carbonate (coccoliths) to form a composite skeleton (coccosphere). Extant coccolithophores exhibit a wide array of coccolith morphologies

Address for correspondence: Odysseas A. Archontikis, Department of Earth Sciences, University of Oxford, South Parks Road, Oxford OX13AN, UK; E-mail: odysseas.archontikis@univ.ox.ac.uk and ultrastructures. In particular, different types of coccoliths are produced during the haploid and diploid phases of the life cycle of most species (Houdan et al. 2006). Diploid cells are typically covered by intracellularly produced heterococcoliths, made of robust, radially arranged crystal segments (Young et al. 1999). Conversely, coccoliths of the haploid phase are usually holococcoliths, composed of numerous, tiny (c. 0.1 $\mu \mathrm{m})$, uniform, regularly arranged, rhombohedral calcite crystallites (Billard 1994; Young et al. 1999, 2005; Houdan et al. 2004). 
The geometrically intricate architecture and varied arrangement of both coccoliths and coccospheres have served as a focal point for calcareous nannoplankton researchers and have led to an impressive set of invaluable taxonomic literature and a series of syntheses over the past few decades (e.g. Kleijne 1991, 1992; Young et al. 1997, 2003, 2005; Jordan and Kleijne 1994; Kleijne et al. 2001; Cros and Fortuño 2002; Jordan et al. 1995, 2004; Frada et al. 2010). As a result, extant coccolithophore taxonomy has greatly advanced with more detailed systematic analyses of coccolith structure being conducted and further life-cycle associations being recognised. Similarly, molecular genetics have been increasingly applied amongst nannoplankton (e.g. Hagino et al. 2009; Young et al. 2014), and along with morphological observations of cultured species (e.g. Edvardsen et al. 2000; Fujiwara et al. 2001; Sáez et al. 2004), new taxonomic reviews are produced. Nonetheless, there are still many coccolithophore taxa that are only informally described and there is a need for taxonomic revision and formal description of several groups and identification of life-cycle associations.

Amongst modern taxa, about 90 different specieslevel morphotypes of holococcolithophores have been described (Young et al. 2003, 2005). Most of these were originally proposed as separate species, but for about one third of them, life-cycle associations with heterococcolithophores have been established and the taxonomy has been revised (e.g. Parke and Adams 1960; Kleijne 1991; Thomsen et al. 1991; Cros et al. 2000; Geisen et al. 2002; Frada et al. 2009; Triantaphyllou et al. 2016; Šupraha et al. 2018; Keuter et al. 2019). This leaves the taxonomic treatment of the remaining species for which life-cycle associations have not been established increasingly problematic. Traditionally, all holococcolithophores were placed in the family Calyptrosphaeraceae Boudreaux and Hay 1969 (Kleijne 1991; Jordan and Green 1994; Jordan and Kleijne 1994; Young and Bown 1997). More recently, several studies (e.g. Young et al. 2003; Jordan et al. 2004) suggested abandonment of this name, as the grouping is taxonomically artificial and instead an informal 'Holococcoliths' category is often used. At generic level, the problem is becoming harder to ignore, especially where some members of a holococcolith genus have recognised life-cycle associations, but others do not. This paper deals with one such genus.

The genus Anthosphaera Kamptner 1937 emend. Kleijne 1991 has been used for a distinctive set of extant holococcolithophores including four formally described species and at least five additional morpho- types, which are poorly documented, but assumed to be of species-level (Cros and Fortuño 2002; Young et al. 2020 Nannotax website). One of the formally described species, Anthosphaera fragaria has been shown to be a life-cycle phase of Syracosphaera molischii, and an informally described form has been shown to represent a life-cycle phase of $S$. marginiporata. In the present work, we provide an illustrated overview and classification of all the Anthosphaera-type holococcoliths currently known, including formal descriptions of several morphotypes.

\section{MATERIALS AND METHODS}

We have reviewed the archived Scanning Electron Microscope (SEM) images of our collections and examined micrographs of extant Anthosphaera specimens from plankton material. The samples used in the present work have been collected over an extended period of time and as part of different sampling programmes that were carried out during different expeditions, undertaken in various oceanic environments (see Fig. 1): the North and South Atlantic Oceans, the Eastern Pacific Ocean, the North Sea as well as the Northwestern Mediterranean and the Adriatic Seas. Information about all used samples and specimens is given in Table 1.

\section{Plankton sampling}

In all expeditions, plankton sampling has typically involved the usage of 5L Niskin bottles, except for the APNAP I Expedition, during which water samples were obtained via 30L Niskin bottles. The Niskin bottles were usually mounted on rosette samplers with attached CTD device for recording salinity, temperature and depth.

\section{Filtering process and SEM}

Filtration process of seawater involved the usage of a vacuum pump and of $25 \mathrm{~mm}$ diameter Whatman Nuclepore polycarbonate track-etched filters, which were normally rinsed with tap water, oven-dried at $\sim 40^{\circ} \mathrm{C}$ and subsequently stored in $47 \mathrm{~mm}$ diameter Millipore plastic petri-dishes for later analyses. A representative segment of each filter was then mounted on a stub, sputter-coated with goldpalladium and examined by electron microscopy. Investigation of the nannoplankton assemblages and imaging were carried out at the facilities of both the Institut Ciències del Mar (CSIC) Barcelona and the Natural History Museum (NHM) London by utilising, respectively, a Hitachi S-570 and/or a Hitachi S-3500N SEM and a Phillips XL-30 FEG field emission SEM. Two samples of this study were examined at the facilities of the University of Amsterdam using an ISI DS130 SEM.

\section{Terminology}

Taxonomic revisions have followed the principles of International Code of Nomenclature (Turland et al. 2018). Detailed morphological descriptions have been given using the terminology proposed in Kleijne (1991), Jordan et al. (1995) and in Young et al. (1997). 
Table 1. List of sampling stations with coordinates and depths, from which Anthosphaera spp., were collected. Specimens not illustrated but used in this study, are indicated with (-).

\begin{tabular}{|c|c|c|c|c|c|c|c|}
\hline Study Area & Station & Latitude $\left({ }^{\circ} \mathrm{N}\right)$ & Longitude $\left({ }^{\circ} \mathrm{E}\right)$ & Depth (m) & $\begin{array}{l}\text { Research Vessel } \\
(\mathrm{R} / \mathrm{V})\end{array}$ & Sampling Date & Figure \\
\hline \multicolumn{8}{|c|}{ Western Mediterranean Sea } \\
\hline \multirow[t]{3}{*}{ Fans-1 } & 64 & 40.585 & 1.118 & 5 & R/V García del Cid & 04-11-1996 & 6.4 \\
\hline & 100 & 40.283 & 0.917 & 25 & ” & 07-11-1996 & 3.2 \\
\hline & 127 & 39.868 & 0.900 & 25 & ” & 08-11-1996 & 3.1 \\
\hline Fans-3 & M11 & 39.885 & 1.016 & 20 & ” & $15-07-1997$ & 1.1 \\
\hline \multirow[t]{3}{*}{ Fronts-95 } & $20 \mathrm{I}$ & 41.018 & 2.668 & 15 & ” & 21-06-1996 & 1.2 \\
\hline & 23D & 40.667 & 2.866 & 30 & ” & 22-06-1995 & 4.2 \\
\hline & $23 \mathrm{D}$ & 40.667 & 2.866 & 50 & ” & & $1.5,3.3,3.4$ \\
\hline \multirow[t]{4}{*}{ Meso-96 } & $\mathrm{E} 3 / 4$ & 41.383 & 3.167 & 20 & ” & 01-07-1996 & 4.1 \\
\hline & $\mathrm{E} 3 / 4$ & 41.383 & 3.167 & 40 & ” & & $4.3,5.1,5.2$ \\
\hline & $\mathrm{G} 2$ & 41.334 & 2.552 & 20 & ” & 24-06-1996 & 4.4 \\
\hline & G4 & 41.334 & 2.552 & 5 & $"$ & 24-06-1996 & 6.3 \\
\hline \multirow[t]{2}{*}{ Hivern-99 } & 25 & 40.317 & 2.750 & 60 & $"$ & 21-02-1999 & 1.4 \\
\hline & 69 & 41.133 & 2.450 & 20 & , & 03-1999 & 2.1 \\
\hline Snellius-II Gx & $186-\mathrm{Gx}$ & 37.577 & 8.396 & 5 & R/V Tyron & 27-06-1985 & - \\
\hline \multirow[t]{2}{*}{ Famoso-3 } & F3-257 & 41.499 & 3.495 & 20 & $\begin{array}{l}\mathrm{R} / \mathrm{V} \text { Sarmiento de } \\
\text { Gamboa }\end{array}$ & 14-09-2009 & $2.3,5.3$ \\
\hline & F3-258 & 41.483 & 4.804 & 20 & , & 15-09-2009 & - \\
\hline \multirow[t]{2}{*}{ L'Estartit } & $26 / 03 / 2012$ & 42.050 & 3.250 & 20 & Fishing boat $-L a$ & 26-03-2012 & 2.2 \\
\hline & $26 / 03 / 2012$ & 42.050 & 3.250 & 50 & Fiera del Mar & & 2.4 \\
\hline \multicolumn{8}{|c|}{ Mediterranean \& Alboran Seas } \\
\hline \multirow[t]{2}{*}{ MATER II } & $69-11$ & 37.430 & 0.420 & 42.5 & R/V Hesperides & $10-1999$ & $6.1,6.2$ \\
\hline & $69-13$ & 37.430 & 0.420 & 30 & $"$ & & - \\
\hline \multicolumn{8}{|l|}{ Adriatic Sea } \\
\hline Rovinj & TS 17-8-09 & 45.040 & 13.630 & 10 & $\mathrm{R} / \mathrm{V}$ Villa Velebita & 08-2009 & $1.6,4.5$ \\
\hline \multicolumn{8}{|c|}{ North Atlantic Ocean } \\
\hline \multirow[t]{2}{*}{ APNAP I } & FB70 & 40.620 & -20.080 & 50 & R/V Tyron & 02-09-1986 & - \\
\hline & T86-C-57F & 31.417 & -36.239 & 5 & ” & & 4.6 \\
\hline P233 & P233b-2 & 29.750 & -17.930 & 25 & R/V Poseidon & 09-1997 & 5.4 \\
\hline \multicolumn{8}{|c|}{ South Atlantic Ocean } \\
\hline AMT16 & 17 & -22.000 & -25.000 & 52 & $\begin{array}{l}\mathrm{R} / \mathrm{V} \text { James Clark } \\
\text { Ross }\end{array}$ & 05/06-2005 & - \\
\hline \multirow[t]{2}{*}{ AMT18 } & CTD089 & -32.180 & -29.830 & 48 & ” & $10 / 11-2008$ & - \\
\hline & CTD089 & -32.180 & -29.830 & 60 & " & & 1.3 \\
\hline \multicolumn{8}{|c|}{ Eastern Pacific Ocean } \\
\hline BIOSOPE & CTD192 & -33.360 & -78.110 & 2 & $\mathrm{R} / \mathrm{V}$ L'Atalante & $10 / 12-2004$ & - \\
\hline \multicolumn{8}{|l|}{ North Sea } \\
\hline Bergen & Alge-26 & 60.400 & 5.300 & 0 & Use of a bucket & $10-2008$ & - \\
\hline
\end{tabular}




\section{OBSERVATIONS AND DISCUSSION}

The genus Anthosphaera is a distinctive extant holococcolithophore, which forms dimorphic coccospheres, typically composed of two characteristic types of holococcoliths (see Fig. 2): circum-flagellar coccoliths with large flattened single-layered ('leaf-like') processes - usually termed fragarioliths, and dome-shaped body coccoliths - sometimes termed calyptroliths. The bodycoccoliths (BCs), which are built on an organic baseplate, consist of 1) a rim and 2) a central structure that embraces a perforate cycle and a distal cover. The rim is a single crystallite thick and is usually joined to the central structure by radial struts. The central structure may be conical or dome-shaped, usually bearing an apical boss on its distal cover and in most forms, it often appears to be hollow rather than solid, although observations of more specimens are needed to determine if this is always the case. The circum-flagellar coccoliths (CFCs) are similarly constructed on an organic baseplate and are elliptical in shape, consisting of 1) a rim and 2) a prominent vertical process. This process is composed of an arched lower part and a 'leaf-like' extension oriented parallel to the long-axis of the coccolith. The process is variable in shape and in the relative size of the arch and leaf. Both the body coccoliths and the circum-flagellar coccoliths are distinctive and the combination clearly separates Anthosphaera from other holococcolithophores. For example, Helladosphaera also forms CFCs with leaf-like processes, which however, are double-layered with a well-developed tube and the BCs are completely different. Conversely, Sphaerocalyptra has somewhat similar tubeless BCs, although lacking the perforate cycle, but forms CFCs with tubular or conical protrusions, not arches with leaf-like extensions.

The species-level taxonomy of Anthosphaera is, however, confusing, mainly because the taxon is both rather rare and morphologically variable. Kamptner (1936) was the first to mention the genus Anthosphaera and its type species, A. fragaria, although he formally described both in 1937. Since then, the name $\mathrm{An}$ thosphaera fragaria in particular, has been used rather loosely often including specimens, which do not closely conform to the holotype images or description. This has subsequently led to significant confusions regarding its classification and the entire group has been switched between two other genera, the holococcolith-bearing Helladosphaera (Gaarder 1962; Norris 1984) and the heterococcolith-producing Algirosphaera (Gaarder and Hasle 1971). More recently though, Kleijne (1991) provided a solid taxonomic revision of the genus, as she both noted significant differences between Helladosphaera and Anthosphaera in terms of coccolith morphology and described new species of Anthosphaera. Her revision broadly remains in use, the consensus view of its present systematics.

As noted above, the taxa that are conventionally included in Anthosphaera show a unique combination of body-coccolith and circum-flagellar coccolith morphologies, and hence, they almost certainly represent a natural group. However, the type species, A. fragar$i a$, has been shown by Triantaphyllou et al. (2016) to be a life-cycle phase of Syracosphaera molischii and therefore, it is now placed in the genus Syracosphaera. Consequently, Anthosphaera Kamptner 1937 is a junior synonym of Syracosphaera Lohmann 1902, and leaves the problem of what to do with the other species of the genus. Young et al. (2003) explicitly ignored such anomalies in holococcolithophore taxonomy on the grounds that they would be resolved by new data. Jordan et al. (2004) took a more nomenclaturally rigorous approach and proposed use of the artificial, but valid genus Holococcolithophora for such orphan species. In the case though of Anthosphaera, there is now additional evidence supporting a consistent association with Syracosphaera. Supraha et al. (2018) showed that Anthosphaera sp. type B of Cros and Fortuño (2002) is a life-cycle phase of $S$. marginiporata. The same authors also showed that Corisphaera strigilis Gaarder 1962 was the holococcolith-producing phase of Syracosphaera hirsuta Kleijne and Cros 2009, and eventually recombined the species as $S$. strigilis. Similarly, Kleijne (1991) documented a combination coccosphere involving the Syracosphaera sp. type A heterococcolith with another holococcolithophore (Syracosphaera sp. type A holococcolith stage) that was considered to show affinities with Zygosphaera (Kleijne 1991); Kleijne and Cros (2009) later formalised this association as Syracosphaera nana (Kamptner 1941) Okada and McIntyre 1977 emend. Kleijne and Cros 2009. This is relevant, since both the strigilis-type and nanatype holococcoliths have many similarities with the Anthosphaera-type holococcoliths; the main difference is that the BCs have a bridge-like protrusion (strigilistype) and lack the perforate cycle (strigilis- and nanatypes). It is also noteworthy that the heterococcoliths of $S$. molischii, S. marginiporata and $S$. strigilis display multiple similarities (Cros 2000) and have all been in- 
cluded in the Syracosphaera molischii group (Young et al. 2003; Kleijne and Cros 2009).

In summary, the group of holococcoliths conventionally placed in Anthosphaera have a distinctive set of morphological characters, which suggest they are closely related, and two of them have been shown to be in life-cycle phases of a distinctive sub-group of Syracosphaera. Hence, it is reasonable to predict that all the Anthosphaera-type holococcolithophores are associated with heterococcolithophores of Syracosphaera, and most likely of the $S$. molischii group. Given this, erecting a new genus for the species, which are not yet proven to belong to Syracosphaera appears to be unnecessary and instead, we propose transferring all the former $\mathrm{An}$ thosphaera species to Syracosphaera. A precedent for this revision is provided by Thomsen et al. (1991), who transferred all Turrisphaera species to Papposphaera, even though, some of them did not have definitively established heterococcolith phases. Syracosphaera is already a large genus with c. 35 extant species, and our study will expand it further. Interestingly, based on previously-noted life-cycle associations, it already accommodates numerous species of several holococcolith-bearing genera, the most common of which are $\mathrm{An}$ thosphaera (Cros and Fortuño 2002; Triantaphyllou et al. 2016; Skejić et al. 2018; Šupraha et al. 2018), Corisphaera (Cros et al. 2000; Geisen et al. 2002; Dimiza et al. 2008; Daniels et al. 2014; Šupraha et al. 2018), Helladosphaera (Cros et al. 2000; Cros and Fortuño 2002; Young and Geisen 2002; Keuter et al. 2019) and Zygosphaera (Kleijne 1991; Cros et al. 2000; Dimiza et al. 2008; Daniels et al. 2014). However, molecular genetic data on the phylogenetic relationships of these species is not yet available and any subdivision of the genus, which was proposed now, would almost certainly be revised, as molecular genetic data became available. Therefore, to avoid repeated reclassifications, we prefer not to formally subdivide Syracosphaera.

In addition to recombining the described species, we also provide formal descriptions for the informally proposed taxa and discuss their discrimination.

\section{SYSTEMATIC TAXONOMY}

Formal descriptions are given here for the holococcolith-bearing phases of all species with Anthosphaeratype holococcoliths. Following Cros et al. (2000) and Young et al. (2003), we add the informal term 'HOL' after the citation to indicate that the holococcolith-bearing phase is being described.

Species Syracosphaera molischii Schiller 1925 HOL

Syracosphaera molischii Schiller 1925 var. molischii HOL

Synonymy: Anthosphaera fragaria (Kamptner) Kamptner 1937, p. 304, Pl. 15, Fig. 20; Kamptner (1941), pp. 86, 106, P1. 9, Figs. 89, 90a, b.

Helladosphaera fragaria (Kamptner) Gaarder (1962), pp. 47, 48, Pl. 11, Figs. a, b; Norris (1984), p. 38.

Calyptrolithina fragaria (Kamptner) Norris (1985), p. 625 .

Anthosphaera fragaria Kamptner emend. Kleijne (1991), p. 39, Pl. VIII, Figs. 3-6; Aubry (1999), pp. 244-246, Figs. 1-3; Cros et al. (2000), Pl. 8, Fig. 1; Cros (2001), pp. 80, 101, Pl. 55, Figs. 1-3 and Pl. 84, Fig. 1; Cros and Fortuño (2002), p. 59, Figs. 86A, 86B; Young et al. (2003), p. 90, Plate 42, Figs. 1, 4; Dimiza (2006), p. 82, Pl. XXVI, Figs. 1-3; Malinverno et al. (2008), p. 136, Fig. 108.

Syracosphaera molischii Schiller 1925 HOL, Triantaphyllou et al. (2016), pp. 466-467, Figs. 5, 6.

Description: Coccosphere spherical, but usually seen collapsed, consisting of c. 60-70 BCs and c. 5-10 CFCs. BCs elliptical in shape forming a flat, well-developed rim that is tightly connected to the central structure by a narrow perforate cycle with single-crystallite width perforations that are barely visible. CFCs possess an arched process with a large leaf-like extension; lower part of leaf is composed of angular microcrystallites, upper part of smoother crystallites and distal margin is delicately serrated.

Dimensions: Coccosphere diameter c. $6-8 \mu \mathrm{m}$. BCs c. $1.1 \mu \mathrm{m}$ long $\mathrm{x} 0.9 \mu \mathrm{m}$ wide. CFCs c. $1.3 \mu \mathrm{m}$ long, distal process c. $2.5 \mu \mathrm{m}$ high.

Species Syracosphaera molischii Schiller 1925 HOL Syracosphaera molischii var. pertusa Archontikis, Young, Cros var. nov. HOL

Synonymy: Anthosphaera fragaria Kamptner emend. Kleijne (1991), Winter and Siesser (1994), p. 148, Fig. 164; Aubry (1999), p. 247, Fig. 4.

Anthosphaera cf. fragaria Kamptner 1937 emend. Kleijne 1991, Cros (2001), p. 80, Pl. 55, Fig. 4; Cros and Fortuño (2002), p. 59, Fig. 86C.

Syracosphaera molischii Schiller 1925 HOL, Godrijan et al. (2018), p. 1703, Fig. 9; Skejić et al. (2018), p. 41, Fig. 8 b. 


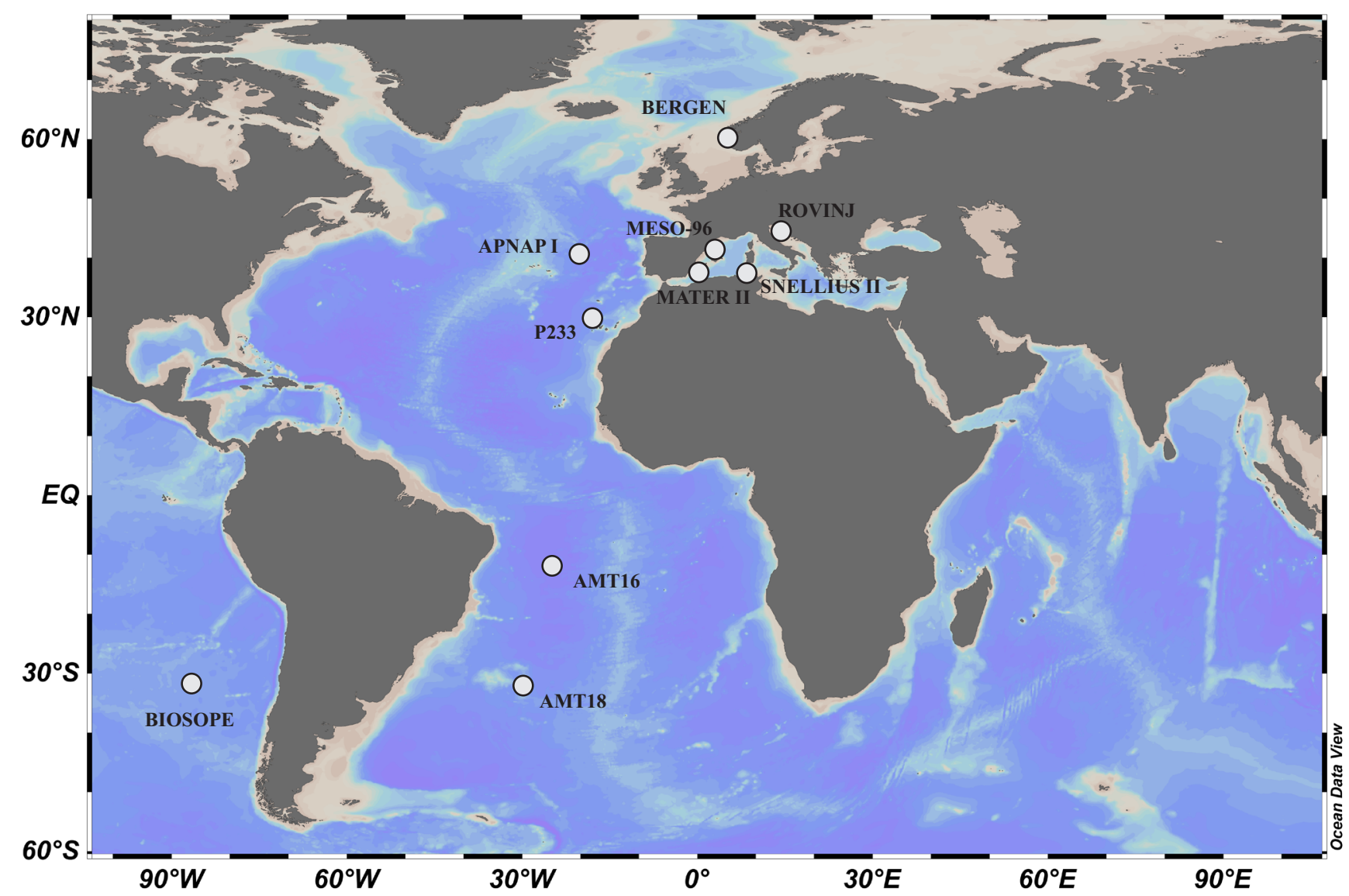

Fig. 1. Map of the sampling locations, where Anthosphaera was observed.

Derivatio nominis: From Latin pertusus $-a-u m$ (adjective), perforated; referring to the somewhat large perforations of the $\mathrm{BCs}$ and the large ones at the base of the CFCs' leaf-life process.

Description: Coccosphere, usually spherical in shape, consisting of c. 50-80 BCs and c. 5-10 CFCs. $\mathrm{BCs}$ elliptical; rim is connected to an elliptical central structure by c. 10-15 radial crystal struts of one large crystal width leaving large perforations at the perforate cycle that are consistently present. The central domelike distal cover is formed of large angular crystallites, which are mostly arranged following the long axis. CFCs elliptical; rim is two to three crystals wide and is connected with a high and broad single-layered arched leaf-like process, made of delicate angular microcrystallites. At the base of the process, several (usually 5) large perforations, can be distinguished.
Remarks: S. molischii var. pertusa HOL is primarily separated from $S$. molischii var. molischii HOL by the larger size of the perforations on the BCs and by the presence of large perforations on the CFCs at the base of the process. In addition, the BCs of S. molischii var. pertusa are smaller and more narrowly elliptical.

Dimensions: Coccosphere diameter c. $5.5 \mu \mathrm{m}$; BCs c. $0.8 \mu \mathrm{m}$ long x $0.6 \mu \mathrm{m}$ wide. CFCs c. $0.7-0.8 \mu \mathrm{m}$ long; distal process c. $2.0 \mu \mathrm{m}$ high.

Holotype: Digital image 151705 (Plate 1, Fig. 4), deposited at ICM (CSIC), Barcelona, Spain.

Paratype: Specimens illustrated at Plate 1, Figs. 5-6.

Type locality: Station Hivern-99 25, $60 \mathrm{~m}$ water depth, collected from the NW Mediterranean Sea $\left(40.82^{\circ} \mathrm{N}, 2.75^{\circ} \mathrm{E}\right)$ on 26 February 1999.

Number of specimens studied: 8

Distribution: Sub-tropical waters. 


\section{Dimorphic Coccosphere}

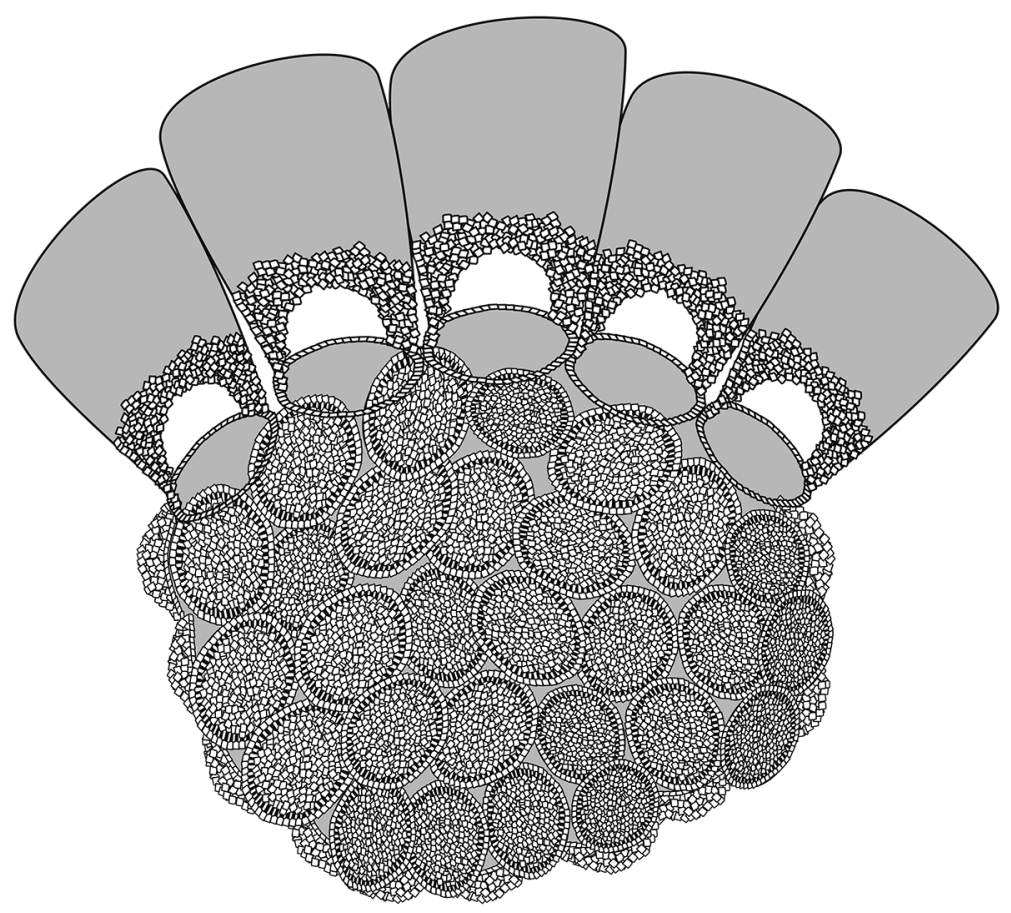

Circum-flagellar coccolith

Body-coccolith
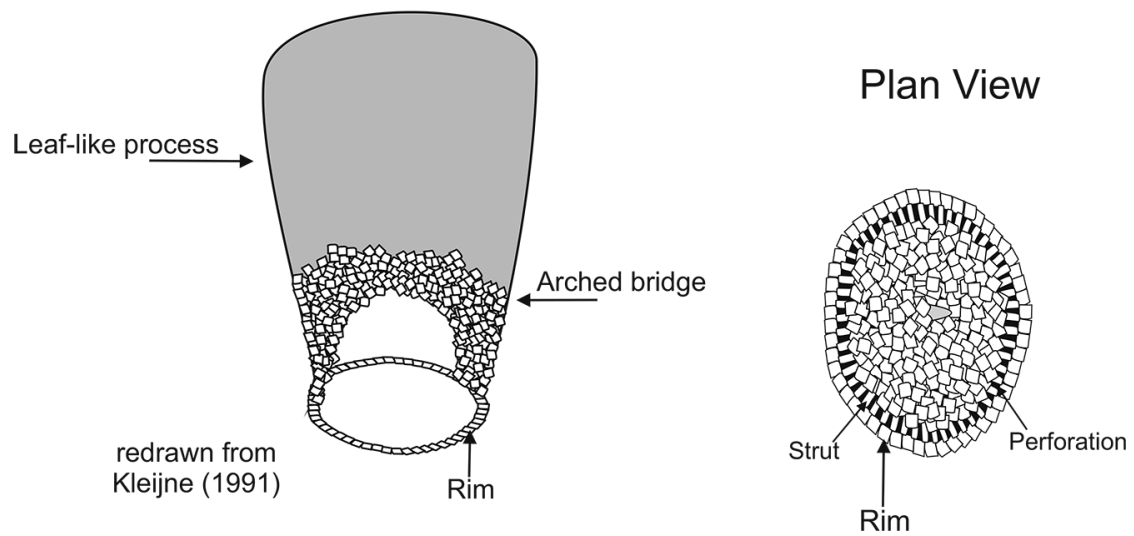

\section{Side View}

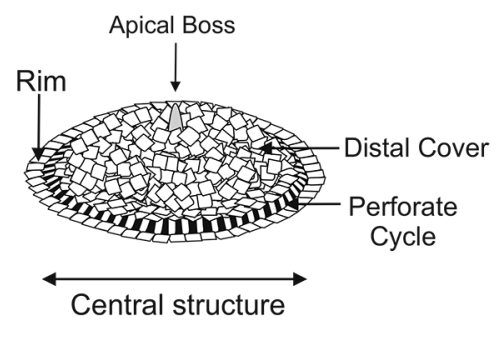

Fig. 2. Schematic representation and terminology of Anthosphaera coccosphere and holococcolith types. 

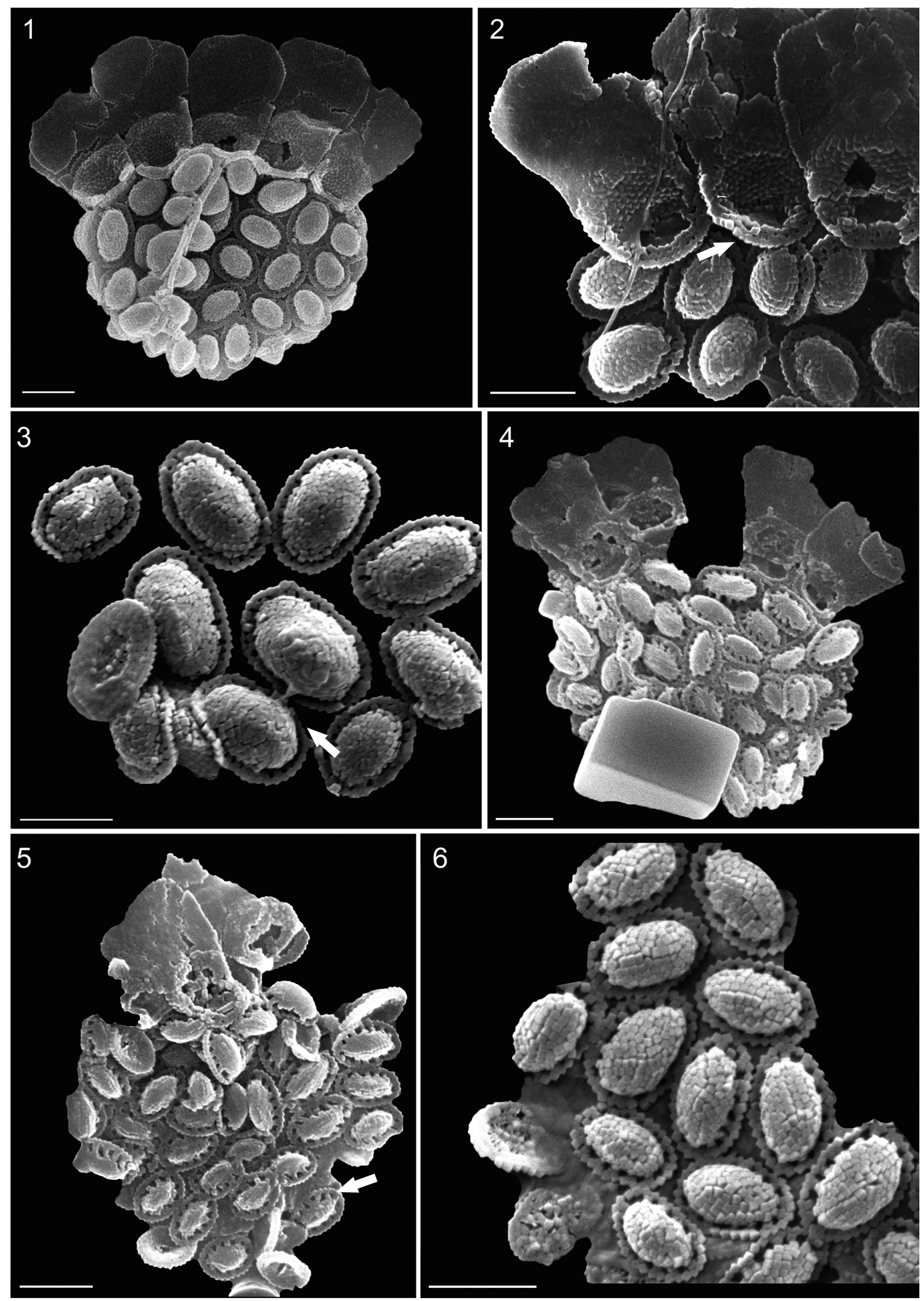
Species Syracosphaera marginiporata Knappertsbusch $1993 \mathrm{HOL}$

Synonymy: Anthosphaera sp. type B Cros and Fortuño (2002), p. 60, Figs. 88B, 112C-112D; Percopo et al. (2011), p. 256, Fig. 30.

Syracosphaera marginiporata HOL Šupraha et al. (2018), p. 27, Fig. 4c.

Description: Coccosphere, spherical but usually seen collapsed, with c. $80-140$ tiny BCs and c. 5-10 CFCs. BCs elliptical, with a single-crystallite-width rim and a rounded central structure, formed from several, usually large, angular crystals typically with openings in between. The rim appears separated from the central structure, i.e. there is a gap, where the perforate cycle would be. CFCs with a large central arch attached to the rim by robust lateral columns of large crystallites; vertical process extends as a large thin leaf with rounded to somewhat straight sides that are constructed by small crystallites arranged in characteristically ordered disposition.

Remarks: BCs' central structure is made by a few crystallites; it is perforated and bears no apical boss or any other structure on top. The perforate cycle does not possess any crystallites. The central structure is not attached to the rim by any visible calcification, but both the rim and the distal cover are supported by an organic baseplate.

Dimensions: Coccosphere diameter c. $4 \mu \mathrm{m}$. BCs c. $0.6 \mu \mathrm{m}$ long x $0.4 \mu \mathrm{m}$ wide. CFCs' distal process is $\mathrm{c}$. $1 \mu \mathrm{m}$ high.

Species Syracosphaera lafourcadii (Lecal 1967) Archontikis, Young, Cros comb. nov. HOL

Basionym: Helladosphaera (Cyclohelladosphaera) lafourcadii Lecal 1967 Hydrobiologia vol. 29, pp. 326328, text-figs. 21, 22, figs. 28-30.

Synonymy: Anthosphaera lafourcadii (Lecal) Kleijne (1991), p. 41, Pl.7 IX, Figs. 1-2; Winter and Siesser
(1994), p. 148, Fig. 165; Aubry (1999), p. 247, Fig. 5; Cros (2001), p. 80, Pl. 55, Figs. 5-6; Cros and Fortuño (2002), p. 148, Fig. 86D; Young et al. (2003), p. 90, P1. 42, Fig. 2; Dimiza (2006), p. 82, Pl. XXVI, Fig. 4; Malinverno et al. (2008), p. 137, Fig. 109.

Description: Coccosphere, spherical in shape, with c. 60-70 BCs and c. 10 CFCs. BCs consist of an elliptical, narrow rim that is tightly connected to a vaulted central structure, made delicately of less regular crystallites. Several struts of one or two crystals width connect the dome-like distal cover with the rim, leaving pores in the perforate cycle, consistently present. No apical boss can be observed on top of the BCs' central distal cover. CFCs possess a broad but low (height similar to width) leaf-like process, with a large arched opening.

Remarks: BCs are similar to those of S. molischii var. molischii $\mathrm{HOL}$, but smaller and with noticeably less regular crystallites. The CFCs are distinctively different, having a well-formed arch and lacking the large leaf-like extension.

Dimensions: Coccosphere diameter c. $4-5 \mu \mathrm{m}$. BCs c. $0.8 \mu \mathrm{m}$ long $\mathrm{x} 0.6 \mu \mathrm{m}$ wide. CFCs' distal process c. $0.8 \mu \mathrm{m}$ high.

Species Syracosphaera origami (Cros and McGrane) Archontikis, Young, Cros comb. nov. HOL

Basionym: Anthosphaera origami Cros and McGrane 2014 J. Nannoplankton Res, vol. 34, p. 2325, P1. 1, Figs. 1-4.

Synonymy: Daktylethra aff. D. pirus (Kamptner) Bérard-Therriault et al. (1999), p. 271, Pl. 132, Fig. a.

Anthosphaera sp. type A (very ornamented; sp. nov. origami?) Cros (2001), p. 81, Pl. 57, Figs. 1-2.

Anthosphaera sp. type A (origami art) Cros and Fortuño (2002), p.150, Fig. 88A; Young et al. (2003) p. 90.

Anthosphaera origami sp. nov. (nomen nudum) Cros (2004), p. 26, Fig. 1.

Plate 1. Syracosphaera molischii Schiller HOL

Scale bars $=1 \mu \mathrm{m}$

1-3. Syracosphaera molischii Schiller var. molischii HOL

1. Complete coccosphere. 2. Detailed view showing the ultrastructure (arrow) of CFCs. 3. Detailed view of BCs showing the angular microcrystallites of the central structure and the tiny perforations at the perforate cycle (arrow).

4-6. Syracosphaera molischii var. pertusa Archontikis, Young, Cros var. nov. HOL

4. Holotype; flattened coccosphere. 5. Paratype; coccosphere with BCs that bear larger (to that of S. molischii var. molischii HOL) perforations on their perforate cycle (arrow). 6. Detailed view of BCs with longitudinally arranged crystals at the central structure. 


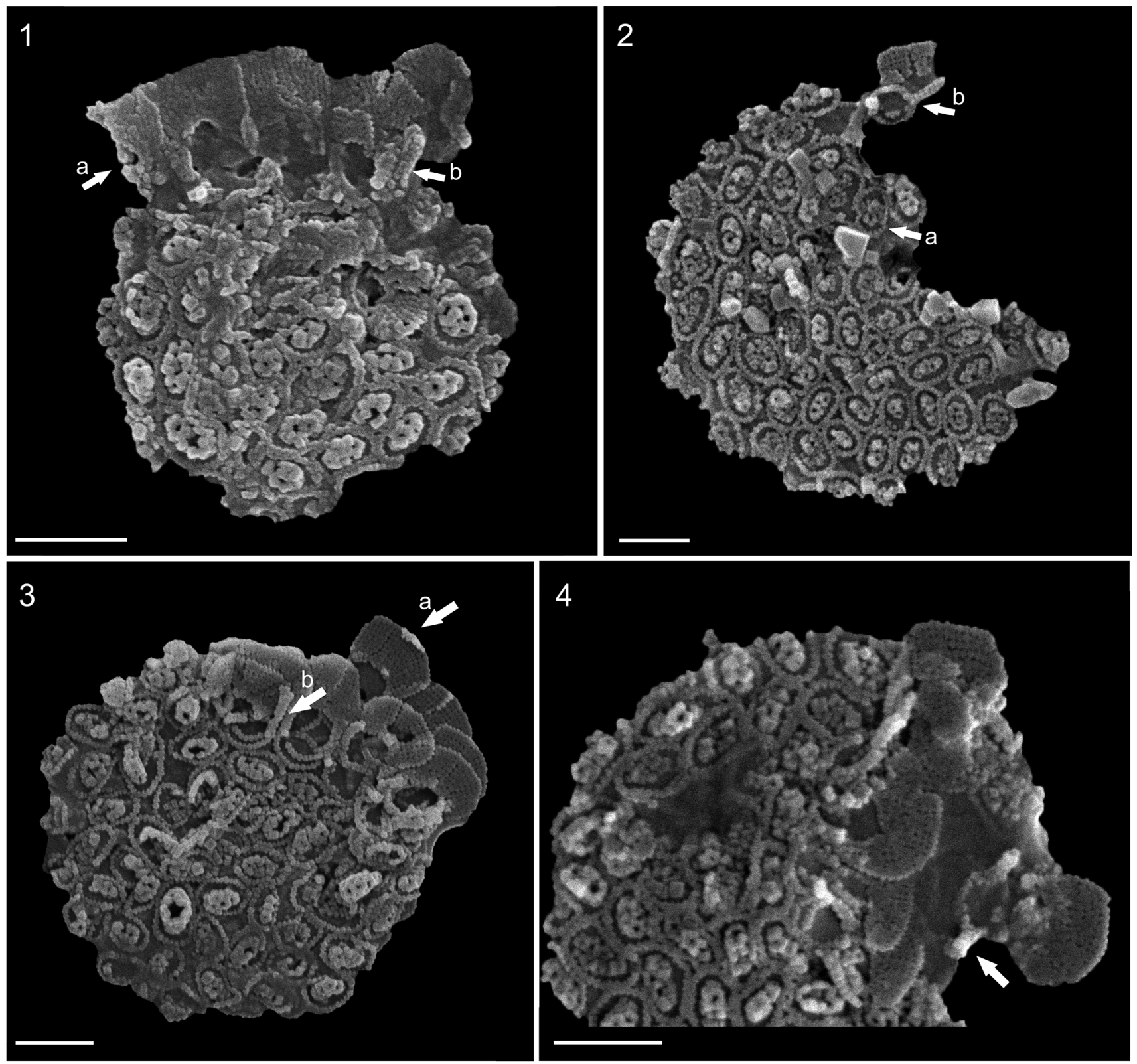

Plate 2. Syracosphaera marginiporata Knappertsbusch HOL

Scale bars $=1 \mu \mathrm{m}$

1. Complete coccosphere with CFCs that show distal processes with straight sides (arrow a) and lateral columns of crystallites (arrow b). 2. Collapsed coccosphere with BCS that leave multiple openings at the central structure (arrow a) and a broken CFC in which the column is attached to the rim (arrow b). 3. Flattened coccosphere with CFCs that bear high processes with rounded to somewhat straight sides (arrow a), sustained by columns of large crystallites (arrow b). 4. Detailed view of specimen showing a broken CFCs with the two columns of crystals (see arrow) attached to the rim and next to the broken distal process (see arrow). 

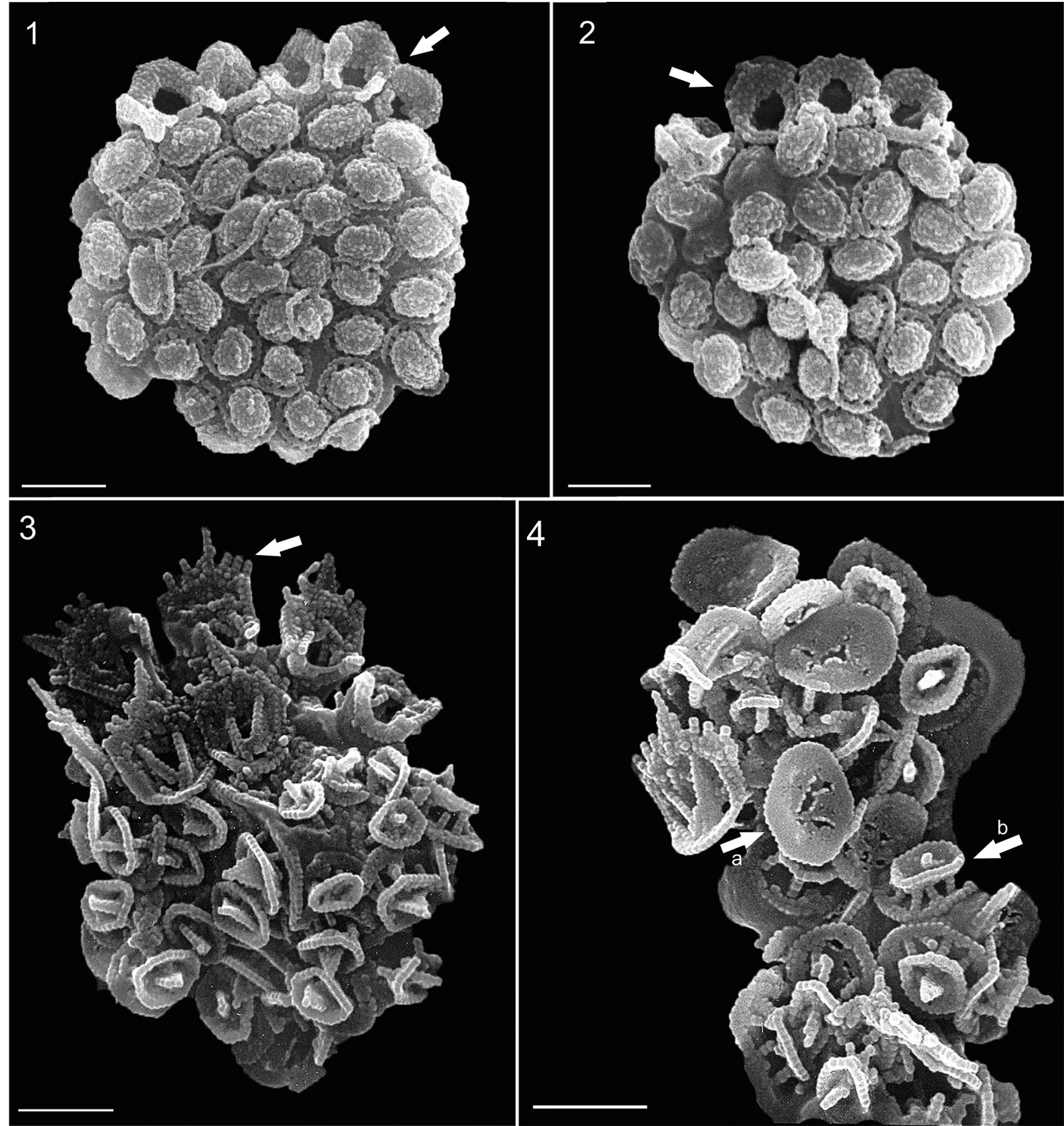

Plate 3.

Scale bars $=1 \mu \mathrm{m}$

1-2. Syracosphaera lafourcadii (Lecal) Archontikis, Young, Cros comb. nov. HOL

Complete coccospheres composed of CFCs that bear low distal processes (see arrows) and BCs with distal covers made of irregularly arranged crystallites.

3-4. Syracosphaera origami (Cros and McGrane) Archontikis, Young, Cros comb. nov. HOL

Coccospheres with highly ornamented CFCs showing triangle-shaped distal processes (fig. 3, arrow) and BCs with an organic base-plate in proximal view (fig. 4, arrow a) and a rim that supports delicate struts of crystallites holding the origami-like paper boat distal covers (fig. 4 , arrow b) in distal view. 
Anthosphaera periperforata (Kleijne) Dimiza (2006), p. 82, Pl. XXVI, Fig. 5; Malinverno et al. (2008), p. 137, Fig. 110.

Anthosphaera origami sp. nov. McGrane (2007) (unpublished PhD thesis, invalid), p. 243, P1. 25, Figs. 1-6.

Description: Coccosphere, usually spherical, composed of c. $40-80$ BCs and c. 5-10 CFCs, all ornamented. BCs elliptical with a two crystallites-width rim, which supports c. 10 robust radial struts of about three crystallites separated by large perforations. The perforate cycle supports a concave distal cover with a central triangular apical boss that is flattened parallel to the long axis of the coccolith. CFCs elliptical and their rim supports an ornamented arched process ending distally in c. 6 spine-like struts of crystallites and a central triangular apical spine. Within the arch, oblique buttresslike sets occur giving an ornamented appearance.

Dimensions: Coccosphere diameter c. $5 \mu \mathrm{m}$. BCs $1.0 \mu \mathrm{m}-1.4 \mu \mathrm{m}$ long x c. $0.8 \mu \mathrm{m}$ wide. CFCs c. $1.0 \mu \mathrm{m}$ wide with a distal process of c. $1.5 \mu \mathrm{m}$ high.

Species Syracosphaera periperforata (Kleijne) Archontikis, Young, Cros comb. nov. HOL

Basionym: Anthosphaera periperforata Kleijne 1991 Mar. Micropaleontol, vol. 17, p. 41, Plate IX, Figs. 3-4 non Figs. 5-6.

The species $S$. periperforata $\mathrm{HOL}$ is characterised by body-coccoliths, with a prominent perforate cycle. The perforations are elongate and typically show consistent anticlockwise obliquity in distal view. The central structure may be domal or conical. The circumflagellar coccoliths have similarly constructed rims, with medium-sized arched processes (c. 1.0-1.5 $\mu \mathrm{m}$ long). It is an unusual taxon among extant holococcolithophores in showing strong chirality; if the perforations are oblique, they are always directed anticlockwise in distal view. The species is morphologically variable (Cros and Fortuño 2002; our observations) in that 1) body-coccoliths and antapical coccoliths may or may not possess an apical boss on top of their central distal cover, 2) the central structure may be conical or dome-shaped, 3) the perforate cycle is variably developed, and 4) circum-flagellar coccoliths may show a flat or a pointed top. If these characters are considered together, then they define a limited number of recurring morphotypes, and we believe these should be regarded as discrete taxa. One of the forms appears sufficiently well-separated to be treated as a distinct species, however, for the other three, the evidence is less clear and therefore, we describe them as varieties.

Syracosphaera periperforata (Kleijne 1991) var. periperforata Archontikis, Young, Cros HOL

Synonymy: Anthosphaera periperforata Kleijne (1991), p. 41, Plate IX, Figs. 3-4; Winter and Siesser (1994), p. 149, Fig. 166; Aubry (1999), p. 248, Fig. 6 (upper panel).

Anthosphaera periperforata type 2 Cros (2001), p. 81, Pl. 56, Figs. 3-4; Cros and Fortuño (2002), p. 59, Fig. 87C; Young et al. (2003), p. 90, Pl. 42, Figs. 3, 6. Anthosphaera sp. Dimiza (2006), p. 83, Pl. XXVI, Fig. 6.

Description: Coccosphere, spherical in shape, composed of c. $40-80 \mathrm{BCs}$ and c. 5-8 CFCs. BCs elliptical rim one crystallite wide, perforate cycle with c. 16 radial struts that show anticlockwise obliquity in distal view; central structure cone-shaped. A short central apical boss always occurs at the top of the protrusion. CFCs elliptical with well-formed arch, supported by robust columns of crystallites, ending distally in a central spine. Additional buttress-like struts of crystallites may also be present within the arch (Plate 4, Fig. 2).

Remarks: BCs' central structure is of conical shape and consistently presents an apical boss on top of its distal cover. The width of the rim is of one crystallite and is connected to the central structure by struts of three to five microcrystals.

\footnotetext{
Plate 4. Syracosphaera periperforata (Kleijne) Archontikis, Young, Cros comb. nov. HOL

Scale bars $=1 \mu \mathrm{m}$

1-2. Syracosphaera periperforata var. periperforata (Kleijne) Archontikis, Young, Cros HOL. 1. Coccosphere with highly arched CFCs (arrow a) and dome-shaped BCs that show an apical boss on top of their central distal cover (arrow b). 2. Detailed view showing the delicate structure of the CFCs' distal process.

3-4. Syracosphaera periperforata var. cylindrata Archontikis, Young, Cros var. nov. HOL. 3. Holotype; Complete coccosphere with higharched CFCs (arrow a) and BCs of cylindrical shape that show no apical boss on top of their central structure; antapical coccoliths (arrow b) always bear an apical boss. 4. Paratype; detailed view showing the proximal (organic) base-plate and the rim of CFCs (arrow).

5-6. Syracosphaera periperforata var. tridentata Archontikis, Young, Cros var. nov. HOL. 5. Holotype; flattened coccosphere with CFCs that bear a low process with a three pointed upper/distal margin structure (arrow a), and a proximal rim with one to two rings of microcrystallites (arrow b); BCs present an apical boss on top of their distal cover. 6. Paratype.
} 
Holococcolithophores: Genus Anthosphaera 133
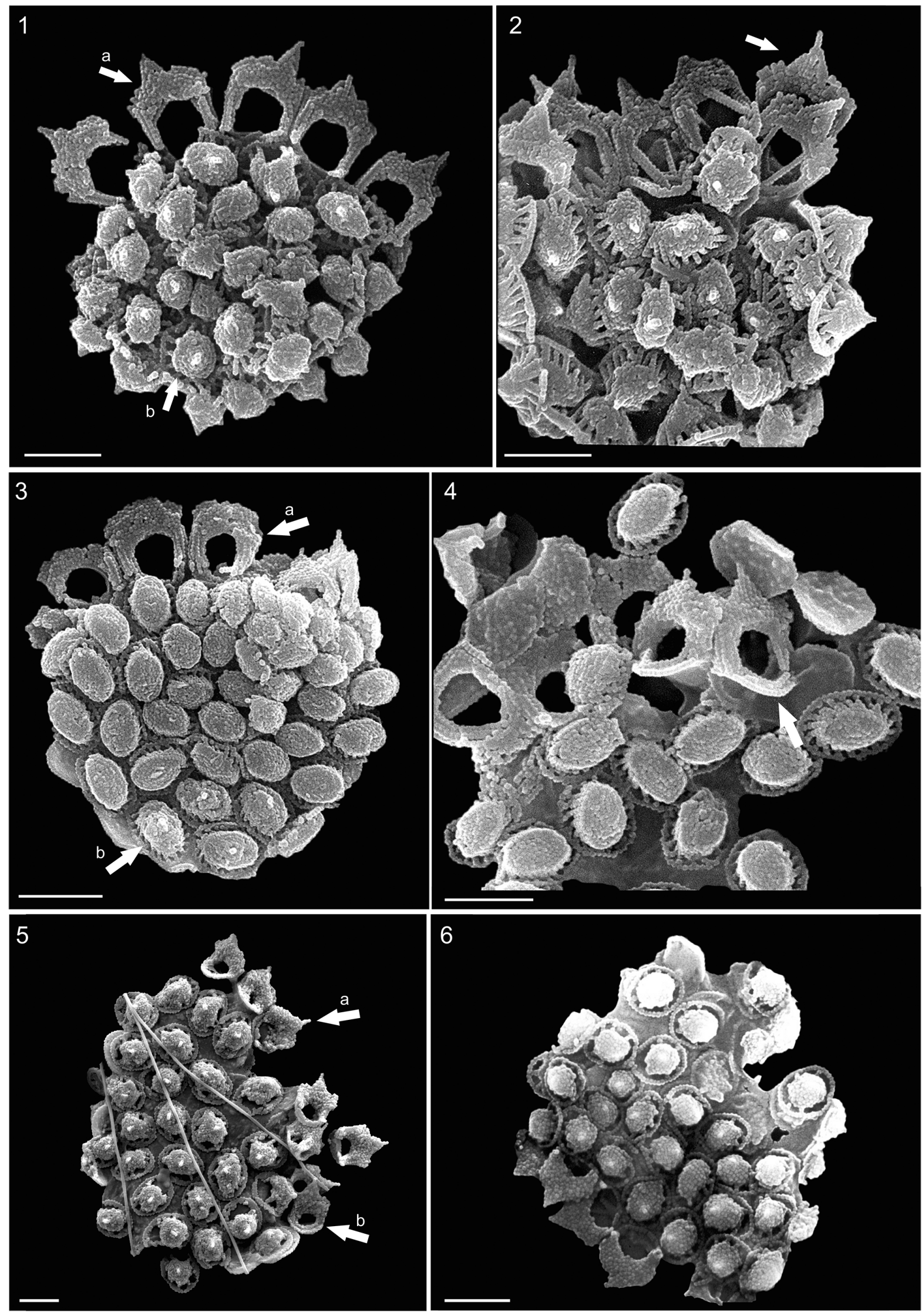
Dimensions: Coccosphere diameter c. $5.5 \mu \mathrm{m}$. BCs c. $1.0 \mu \mathrm{m}$ long x c. $0.8 \mu \mathrm{m}$ wide. CFCs c. $1.0 \mu \mathrm{m}$ long and wide; distal process c. $1.3 \mu \mathrm{m}$ high.

Syracosphaera periperforata var. cylindrata Archontikis, Young, Cros var. nov. HOL

Synonymy: Anthosphaera periperforata Kleijne 1991, p. 41, Pl. IX, Figs. 5-6; Aubry (1999), p. 248, Fig. 6 (lower panel).

Anthosphaera periperforata type 1 Cros (2001), p. 81, Pl. 56, Figs. 1-2; Cros and Fortuño (2002), p. 59, Figs. 87A, 87C; Young et al. (2003), p. 90, P1. 42, Fig. 5.

Derivatio nominis: From Latin cylindratus $-a-u m$ (adjective), cylindrical; referring to the somewhat cylindrical structure of the BCs.

Description: Coccosphere, usually spherical, composed of c. 40-80 BCs and c. 7-14 CFCs. BCs elliptical, rim one crystallite wide and loosely connected to a short cylinder-like distal cover at the central structure via c. 15-20 short, delicate connecting struts of crystal elements. The walls of the cylindrical structure are formed of compacted struts of crystallites, the top is nearly flat and typically without any central apical boss; however, some antapical coccoliths may bear a weak apical boss. CFCs with broad arch, supported by two short but robust columns, often with a central apical spine.

Remarks: The cylindrical form of the protrusion combined with the absence of a central apical boss readily separates the BCs of $S$. periperforata var. cylindrata. The CFCs are less distinctive, but generally less ornamented than those of other varieties.

Dimensions: Coccosphere diameter is c. $6 \mu \mathrm{m}$. BCs c. $1.0 \mu \mathrm{m}$ long x c. $0.7 \mu \mathrm{m}$ wide. CFCs c. $1.0 \mu \mathrm{m}$ long and wide; CFCs' distal process $1.0 \mu \mathrm{m}$ high.

Holotype: Negative ${ }^{\circ} 140501$ (Plate 4, Fig. 3), curated at the ICM (CSIC), Barcelona, Spain.

Paratype: Specimen illustrated at Plate 4, Fig. 4.

Type locality: Station Meso-96 E3/4, 40m water depth, collected from the NW Mediterranean Sea

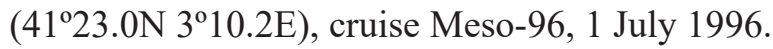

Number of specimens studied: 7

Distribution: Sub-tropical waters

Syracosphaera periperforata var. tridentata Archontikis, Young, Cros var. nov. HOL

Derivatio nominis: From Latin tridentatus $-a-u m$ (adjective), from trident, the three-prong weapon; referring to the three-pointed upper structure of CFCs.
Description: Coccosphere, spherical but usually seen collapsed, composed of c. 50-85 BCs and c. 6-10 CFCs. BCs broadly elliptical with a rim of one to two microcrystals wide. Perforate cycle irregular with $\mathrm{c}$. 8 large perforations, separated by narrow struts, which usually do not show obvious obliquity. The central structure dome-shaped with a low apical boss. CFCs subcircular to circular in outline. A single-layered distal process, whose opening in the arch is placed low, bears an upper margin structure with three pointy edges; the rim shows one to two rings of crystallites.

Remarks: The central structure of the BCs is similar to that of $S$. periperforata var. periperforata with a conical shape and an apical boss. However, the perforate cycle is less regular and bears less struts. The CFCs are also different, showing a characteristic upper margin structure with three pointy edges and a low arch.

Dimensions: Coccosphere diameter c. $7.5 \mu \mathrm{m}$. BCs c. $0.9-1.1 \mu \mathrm{m}$ long x c. $0.8-1.0 \mu \mathrm{m}$ wide. CFCs c. 1.0 $1.2 \mu \mathrm{m}$ long and wide; distal process maximum $1.0 \mu \mathrm{m}$ high and wide.

Holotype: Specimen illustrated in JRYSEM-303-76 (Plate 4, Fig. 5), stub TS 17-8-09, curated at the NHM, London, UK.

Paratype: Specimen illustrated at Plate 4, Fig. 6.

Type locality: Station RV001, 10m water depth, collected off Rovinj, northeastern Adriatic Sea $\left(45^{\circ} 04 \mathrm{~N}\right.$, $13^{\circ} 63 \mathrm{E}$ ) on 17 August 2009.

Number of specimens studied: 7

Distribution: Sub-tropical waters

Species Syracosphaera rotaconica Archontikis, Young, Cros sp. nov. HOL

Synonymy: Anthosphaera periperforata sp. type 3 Cros (2001), p. 81, Pl. 56, Figs. 5-6; Cros and Fortuño (2002), p. 60, Fig. 87D; Young et al. (2003), p. 90, Pl. 42, Figs. 7, 10.

Derivatio nominis: From Latin rota (noun), wheel, and conicus $-a-u m$ (adjective), conical; referring to the chiral-conical structure of the BCs.

Description: Coccosphere spherical shape, usually seen collapsed, composed of 30-80 nearly flat BCs and 5-10 CFCs. BCs' elliptical rim formed of two rings of small crystallites and perforate cycle well-developed with c. 20 struts showing distinct anticlockwise obliquity. These form a simple cone with an apical boss on top of the distal cover. The struts are well-separated by prominent and large, nearly triangular perforations. CFCs consist of a similarly structured rim that bears a distal arched process with a low point via crystal 

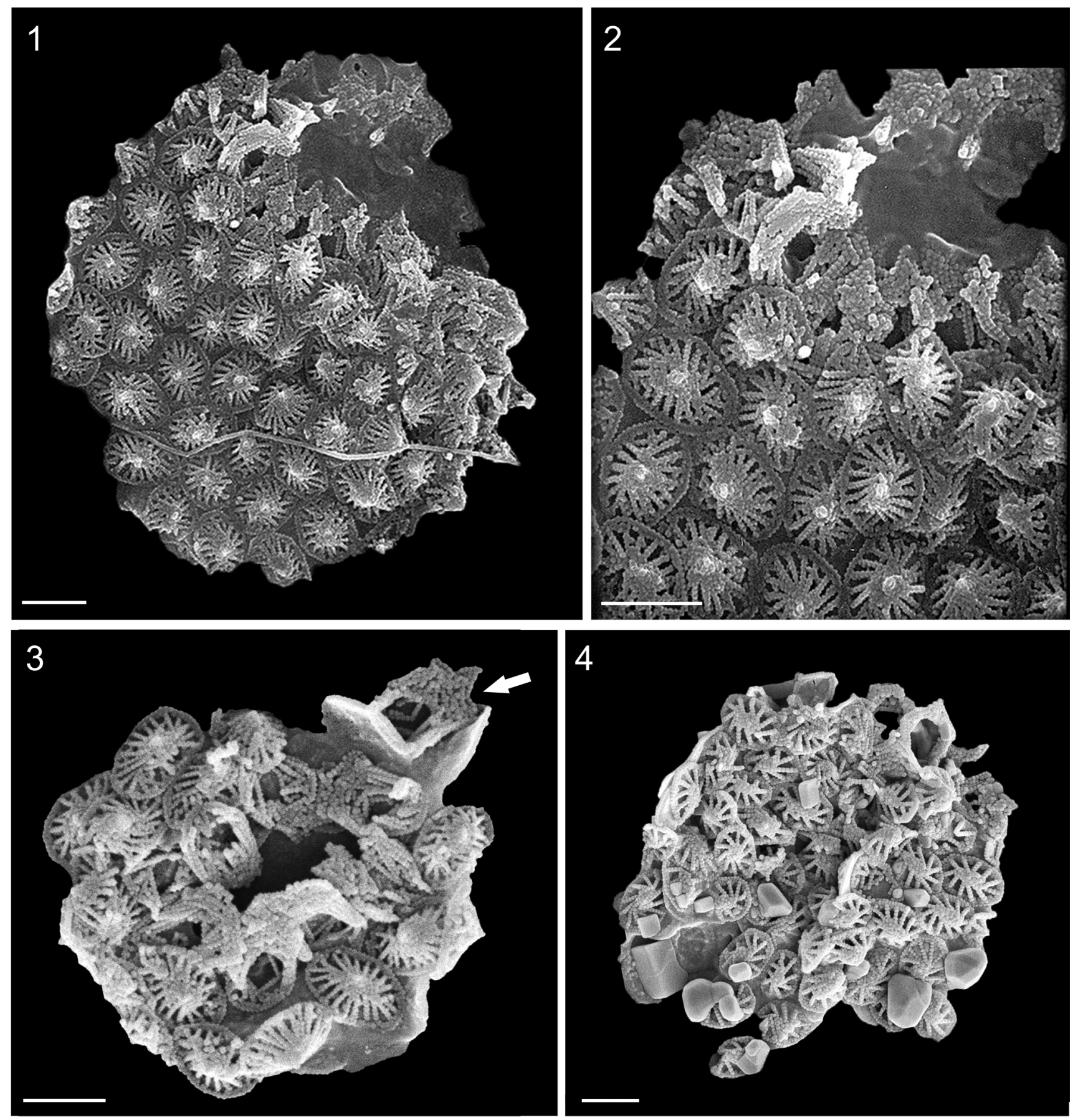

Plate 5. Syracosphaera rotaconica Archontikis, Young, Cros sp. nov. HOL

Scale bars $=1 \mu \mathrm{m}$

1. Holotype; flattened coccosphere with chiral-conical BCs that usually show a small apical boss on top of the central distal cover. BCs' central structure is made of numerous crystal struts, progressively meeting and forming the distal cover. 2 . Detail of figure 1 showing the ultrastructure of BCs. 3. Paratype; coccosphere showing the delicate structure of CFCs (see arrow). 4. Paratype. 

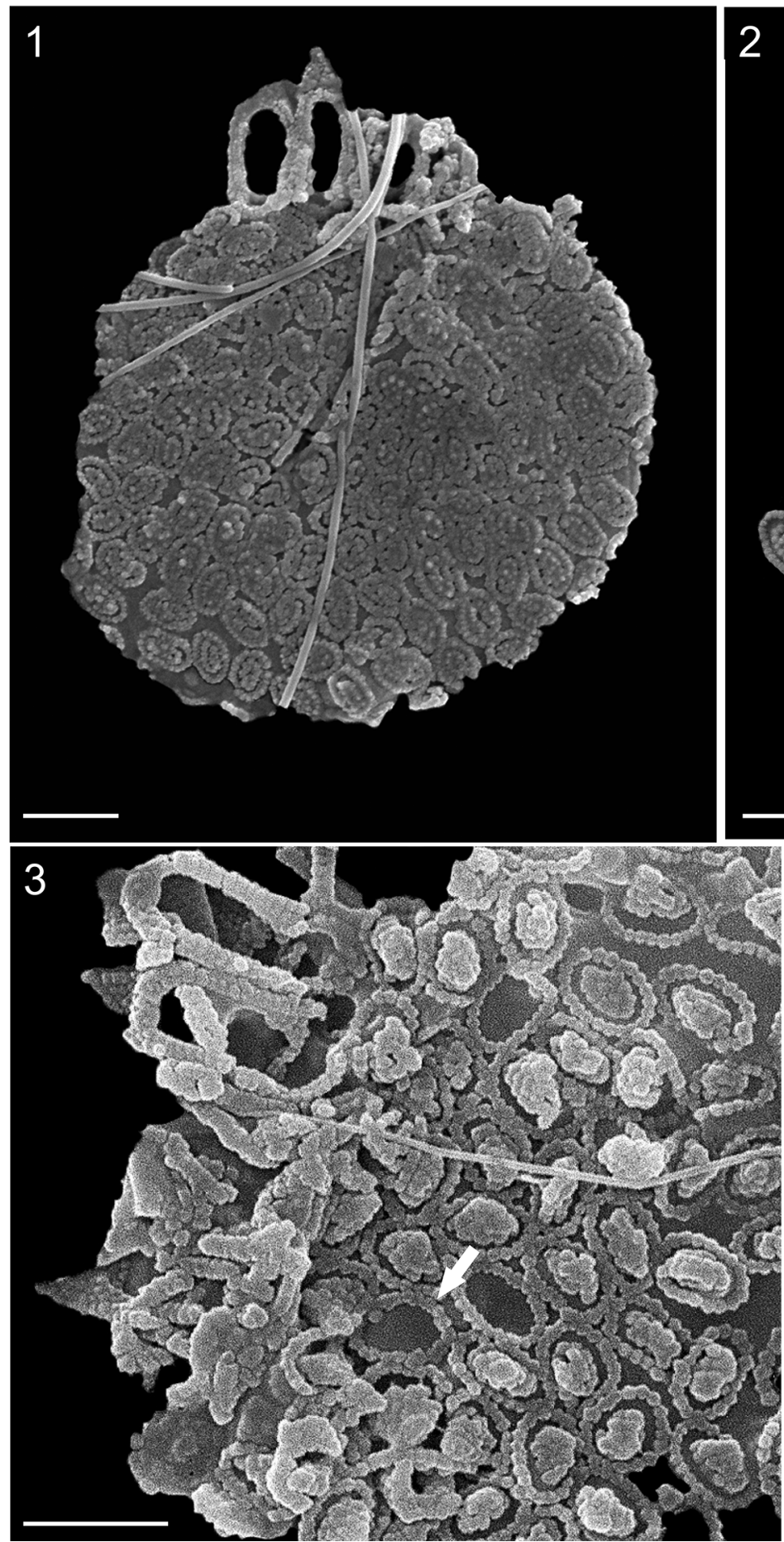
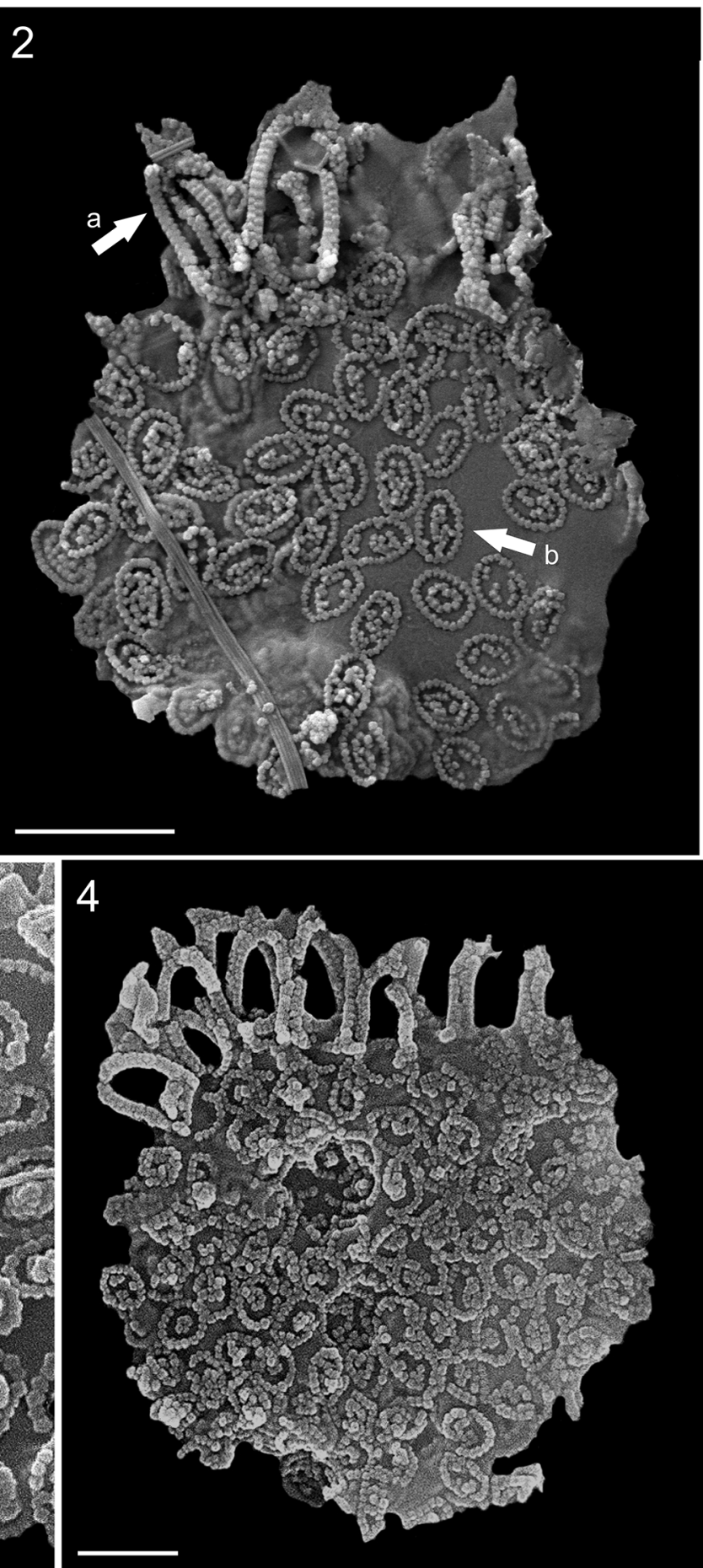

Plate 6. Syracosphaera elevata Archontikis, Young, Cros sp. nov. HOL

Scale bars $=1 \mu \mathrm{m}$

1. Holotype; flattened coccosphere with high-arched CFCs and tiny and partially calcified BCs. 2. Paratype; coccosphere with CFCs that bear distal processes made of delicate microcrystals (arrow a), and BCs with a loose assembly of irregularly arranged microcrystals at their distal cover (arrow b). 3. Paratype; BCs' central structure may lose its crystal assembly (arrow). 4. Paratype. 
struts. The central pointy edge is somewhat higher than the lateral ones.

Remarks: BCs' central structure is conical in shape and similar to that of $S$. periperforata var. periperforata, but smaller. The perforate cycle is made by large struts of crystallites; BCs' rim is of two crystallites wide as opposed to one of the $S$. periperforata var. periperforata rim width.

Dimensions: Coccosphere diameter c. $7.5 \mu \mathrm{m}$. BCs $1.0 \mu \mathrm{m}$ long x $0.8 \mu \mathrm{m}$ wide. CFCs c. $1.3 \mu \mathrm{m}$ long x 0.8 $\mu \mathrm{m}$ wide; CFCs' distal process c. $1.0 \mu \mathrm{m}$ high.

Holotype: Negative $n^{\circ} 140419$ (Plate 5, Fig. 1), curated at the ICM (CSIC), Barcelona, Spain.

Paratype(s): Specimens illustrated at Plate 5, Figs. 3-4.

Type locality: Station Meso-96 E3/4, $40 \mathrm{~m}$ water depth, collected from the NW Mediterranean Sea

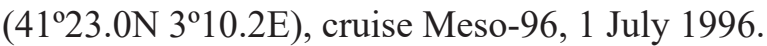

Number of specimens studied: 7

Distribution: Sub-tropical waters

Species Syracosphaera elevata Archontikis, Young, Cros sp. nov. HOL

Synonymy: Holococcolithophore sp. 2 ( $A n-$ thosphaera affinity?) Cros (2001), p. 97, Pl. 75, Figs. 3-4.

Anthosphaera sp. type C Cros and Fortuño (2002), p. 60 , Figs. $88 \mathrm{C}$, $88 \mathrm{D}$; Young et al. (2003), p. 90, Pl. 42, Figs. 8, 11.

Derivatio nominis: From Latin elevatus $-a-u m$ (adjective), elevated; referring to the elevated arch of CFCs.

Description: Coccosphere, most probably spherical in shape but usually seen collapsed/flattened, with c. 250 BCs and 5-12 CFCs. BCs are characteristically minute $(<1 \mu \mathrm{m})$ and partially calcified with an elliptical rim. BCs' rim structure consists of an outer ring of tiny rhombohedral crystals that are loosely connected with an assembly of irregularly arranged, tiny crystallites in the central structure, thus leaving somewhat broad perforations; a few BCs with only a rim sometimes occur (Plate 6, Fig. 3). CFCs consist of a similarly constructed rim, possessing though, a high $\operatorname{arch}$ (height $>2 \mathrm{x}$ width) with a low triangular apical spine.

Remarks: The BCs are similar to those of S. marginiporata, although without the perforate microstructure. The CFCs with the very high arch are unique and quite different to those of $S$. marginiporata.
Dimensions: Coccosphere diameter c. $6 \mu \mathrm{m}$. BCs $0.4-0.8 \mu \mathrm{m}$ long x c. $0.4 \mu \mathrm{m}$ wide. CFCs c. $0.5 \mu \mathrm{m}$ long x $0.5-0.8 \mu \mathrm{m}$ wide; distal process is $1.2-2.0 \mu \mathrm{m}$ high.

Holotype: Specimen illustrated in JRYSEM-177-72 (Plate 6, Fig. 1), stub 302-02, curated at the NHM, London, UK.

Paratype(s): Specimens illustrated at Plate 6, Figs. 3-4.

Type locality: Station $69-11,42.5 \mathrm{~m}$ water depth, collected from the western Mediterranean Sea $\left(37^{\circ} 43 \mathrm{~N}\right.$, 042W), cruise MATER II, October 1999.

Number of specimens studied: 9

Distribution: Northwestern Mediterranean and Alboran Seas

Acknowledgements. We are grateful to the captains and crew of all expeditions during which plankton samples were taken. We warmly thank numerous colleagues for their invaluable help in plankton sampling, with the SEM analysis and with discussion of coccolithophore taxonomy. We particularly appreciate the technical assistance of J.M. Fortuño with the SEM. We acknowledge Drs. Jelena Godrijan and Marta Estrada, who kindly provided samples from the Adriatic and the NW Mediterranean Seas, respectively. Special thanks are due to Dr. Annelies Kleijne for providing the specimen images of samples T86-C-57F and 186-Gx, presented in this study. Previously published micrographs used in this research, have been reproduced with the kind permission of Scientia Marina and Journal of Nannoplankton Research. This study used SEM images from the research projects MEDIPELAGOS (MAS3-CT93-0063), MEDEA (MAS3-CT95-0016), FANS (MAS3-CT95-0037), HIVERN (MAR98-0932), MATER (MAS3-CT96-0051), FAMOSO (CTM2008-06261-C03), MANIFEST (CTM2012-32017) and the EC TMR project CODENET, Coccolithophorid Evolutionary Biodiversity and Ecology Network (FRMX-ET97-0013). O.A.A. was supported by the Natural Environmental Research Council (grant number NE/S007474/1). The manuscript has benefited from the constructive criticism of two anonymous reviewers.

\section{REFERENCES}

Aubry M.-P. (1999) Handbook of Cenozoic calcareous nannoplankton. Book 5: Heliolithae (Zygoliths and Rhabdoliths). New York Micropaleontology Press, American Museum of Natural History: 368 pp.

Bérard-Therriault L., Poulin M. and Bossé L. (1999) Guide d'identification du phytoplancton marin de l'estuaire et du Golfe du Saint-Laurent - incluant également certains protozoaires. Publication spéciale canadienne des sciences halieutiques et aquatiques. 128: $1-387$

Billard C. (1994) Life cycles. In: The Haptophyta Algae (Eds. Green J.C. and Leadbeater B.S.C.). Syst. Ass. Spec. 51: 167-186

Boudreaux J. E. and Hay W. W. (1969) Calcareous nannoplankton and biostratigraphy of the late Pliocene-Pleistocene-Recent sediments in the submarex cores. Revta Esp. Micropaleont. 1: 249-292

Cros L. (2000) Variety of exothecal coccoliths of Syracosphaera. J. Nannoplankton Res. 22: 41-51 
Cros L. (2001) Planktonic coccolithophores of the NW Mediterranean. PhD Thesis, Universitat de Barcelona. Barcelona, 389 pp.

Cros L. (2004) A planktonic coccolithophore with characteristic origami-shaped holococcoliths. J. Nannoplankt. Res. 26 (2): 26

Cros L. and Fortuño J.-M. (2002) Atlas of Northwestern Mediterranean Coccolithophores. Sci. Mar. 66: 186

Cros L. and McGrane P. B. (2014) Anthosphaera origami sp. nov., a planktonic coccolithophore with characteristic paper-boatshaped structures. J. Nannoplankton Res. 34: 23-25

Cros L., Kleijne A., Zeltner A., Billard C. and Young J. R. (2000) New examples of holococcolith-heterococcolith combination coccospheres and their implications for coccolithophorid biology. Mar. Micropaleontol. 39: 1-34

Daniels C. J., Tyrrell T., Poulton A. J. and Young J. R. (2014) A mixed life-cycle stage bloom of Syracosphaera bannockii (Borsetti and Cati, 1976) Cros et al. 2000 (Bay of Biscay, April 2010). J. Nannoplankton Res. 34: 31-35

Dimiza M. (2006) The study of recent coccolithophore biocommunities in the coastal environments of Andros island and their correlation to the late Quaternary formations from central Aegean Sea. PhD Thesis. National and Kapodistrian University of Athens, Greece. 338 pp.

Dimiza M. D., Triantaphyllou, M. V. and Dermitzakis M. D. (2008) Seasonality and ecology of living coccolithophores in Eastern Mediterranean coastal environments (Andros Island, Middle Aegean Sea). Micropaleontology. 54: 159-172

Edvardsen B., Eikrem W., Green J. C., Andersen R. A., Yeo MoonVan Der Staay S. and Medlin L. K. (2000) Phylogenetic reconstructions of the Haptophyta inferred from 18S ribosomal DNA sequences and available morphological data. Phycologia. 39: 19-35

Frada M., Percopo I., Young J. R., Zingone A., de Vargas C. and Probert I. (2009) First observations of heterococcolithophoreholococcolithophore life cycle combinations in the family Pontosphaeraceae (Calcihaptophycideae, Haptophyta). Mar. Micropaleontol. 71: 20-27

Frada M., Young J. R., Cachão M., Lino S., Martins A., Narciso A., Probert I. and de Vargas C. (2010) A guide to extant coccolithophores (Calcihaptophycidae, Haptophyta) using light microscopy. J. Nannoplankton Res. 31: 58-112

Fujiwara S., Tsuzuki M., Kawachi M., Minaka N. and Inouye I. (2001) Molecular phylogeny of the haptophyta based on the rbcL gene and sequence variation in the spacer region of the RUBISCO operon. J. Phycol. 37: 121-129

Gaarder K. R. (1962) Electron microscope studies on holococcolithophorids. Nytt Mag. Bot. 10: 35-51

Gaarder K. R. and Hasle G. R. (1971) Coccolithophorids of the Gulf of Mexico. Bull. Mar. Sci. 21: 519-544

Geisen M., Billard C., Broerse A. T. C., Cros L., Probert I. and Young J. R. (2002) Life-cycle associations involving pairs of holococcolithophorid species: intraspecific variation or cryptic speciation? Eur. J. Phycol. 37: 531-550

Godrijan J., Young J. R., Pfannkuchen D. M., Precali R. and Pfannkuchen M. (2018) Coastal zones as important habitats of coccolithophores: A study of species diversity, succession, and life-cycle phases. Limnol Oceanogr. 63: 1692-1710

Hagino K., Takano Y. and Horiguchi T. (2009) Pseudo-cryptic speciation in Braarudosphaera bigelowii (Gran and Braarud) Deflandre. Mar. Micropaleontol. 72: 210-221

Houdan A., Billard C., Marie D., Not F., Sáez A. G., Young J. R. and Probert I. (2004) Flow cytometric analysis of relative ploidy levels in holococcolithophore-heterococcolithophore (Haptophyta) life cycles. System. Biodivers. 1: 453-465

Houdan A., Probert I., Zatylny C., Véron B. and Billard C. (2006). Ecology of oceanic coccolithophores. I. Nutritional preferences of the two stages in the life cycle of Coccolithus braarudii and Calcidiscus leptoporus. Aquat. Microb. Ecol. 44: 291-301

Jordan R. W. and Green J. C. (1994) A check-list of the extant Haptophyta of the world. J. Mar. Biolog. Assoc. U.K. 74: 149-174

Jordan R. W. and Kleijne A. (1994) A classification system for living coccolithophores, in: Coccolithophores, (Eds. Winter A. and Siesser W. G). Cambridge University Press, Cambridge. 83-105

Jordan R. W., Cros L. and Young J. R. (2004) A revised classification scheme for living haptophytes. Micropaleontology. 50: 55-79

Jordan R. W., Kleijne A., Heimdal B. R. and Green J. C. (1995) A glossary of the extant haptophyte of the world. J. Mar. Biol. Ass. U. K. 75: 769-814

Kamptner E. (1936) Über die Coccolithineen der Südwestküste von Istrien. Anz. Akad. Wiss. Wien. 73: 243-247

Kamptner E. (1937) Neue und bemerkenswerte Coccolithineen aus dem Mittelmeer. Arch. Protistenkd. 89: 279-316

Kamptner E. (1941) Die Coccolithineen der Siidwestkiiste von Istrien. Naturhist. Mus. Wien, Ann. Anz. 51: 54-149

Keuter S., Young J. R. and Frada M. (2019) Life cycle association of the coccolithophore Syracosphaera gaarderae comb. nov. (ex Alveosphaera bimurata): Taxonomy, ecology and evolutionary implications. Mar. Micropaleontol. 148: 58-64

Kleijne A. (1991) Holococcolithophorids from the Indian Ocean, Red Sea, Mediterranean Sea and North Atlantic Ocean. Mar. Micropaleontol. 17: 1-7

Kleijne A. (1992) Extant Rhabdosphaeraceae (coccolithophorids, class Prymnesiophyceae) from the Indian Ocean, Red Sea, Mediterranean Sea and North Atlantic Ocean. Scr. Geol. 100: $1-63$

Kleijne A. and Cros L. (2009) Ten new extant species of the coccolithophore Syracosphaera and a revised classification scheme for the genus. Micropaleontology 55: 425-462

Kleijne A., Jordan R. W., Heimdal B. R., Samtleben C., Chamberlain A. H. L. and Cros L. (2001) Five new species of the coccolithophorid genus Alisphaera (Haptophyta) with notes on their distribution, coccolith structure and taxonomy. Phycologia 40: 583-601

Lecal J. (1967) Le Nannoplancton des Côtes d'Israël. Hydrobiologia 29: 305-387

Malinverno E., Dimiza M. D., Triantaphyllou M. V., Dermitzakis M. D. and Corselli C. (2008) Coccolithophores of the Eastern Mediterranean Sea: A look into the marine microworld. Ion Publishing Group, Peristeri, 188 pp.

McGrane P. B. (2007) Extant coccolithophores in Irish Shelf Waters of the Northeast Atlantic. PhD Thesis. National University of Ireland. Galway, $360 \mathrm{pp}$.

Norris R. E. (1984) Indian Ocean nanoplankton. I. Rhabdosphaeraceae (Prymnesiophyceae) with a review of extant taxa. J. Phycol. 20: $27-41$

Norris R. E. (1985) Indian Ocean nannoplankton. II. Holococcolithophorids (Calyptrosphaeraceae, Prymnesiophyceae) with a review of extant genera. J. Phycol. 21: 619-641

Okada H. and McIntyre A. (1977) Modern coccolithophores of the Pacific and North Atlantic Oceans. Micropaleontology 23: 1-55

Parke M. and Adams I. (1960) The motile (Crystallolithus hyalinus Gaarder and Markali) and non-motile phases in the life-history 
of Coccolithus pelagicus (Wallich) Schiller. J. Mar. Biol. Ass. U. K. 39: 263-274

Percopo I., Siano R., Cerino F., Sarno D. and Zingone A. (2011) Phytoplankton diversity during the spring bloom in the northwestern Mediterranean Sea. Botanica Marina 54: 243-267

Sáez A. G., Probert I., Young J. R., Edvardsen B., Wenche E. and Medlin L. K. (2004) A review of the phylogeny of the Haptophyta, in: Coccolithophores - from molecular processes to global impact, (Eds. Thierstein H. R. and Young J. R.). Springer, 251-270

Schiller J. (1925) Die planktonischen Vegetationen des adriatischen Meeres. A. Die Coccolithophoriden-Vegetation in den Jahren 1911-14. (Nach den Ergebnissender 6sterreichischen Adriaforschung in den Jahren 1911-14.) Arch. Protistenkd. 51: 1-130

Schlauder J. (1945) Recherches sur les flagellés calcaires de la Baie d'Alger. Diplôme D'Etudes Supérieures (Zoologie), Faculté des Sciences, Université d'Alger, Algiers, 1-51

Skejić S., Arapov J., Kovačević V., Bužančić M., Bensin M., Giani M., Bakrač A., Mihanović H., Ninčević Gladan Z., Urbini L. and Grbec B. (2018). Mar. Micropaleontol. 143: 30-45

Šupraha L., Ljubešić Z. and Henderiks J. (2018) Combination coccospheres from the Eastern Adriatic coast: New, verified and possible life-cycle associations. Mar. Micropaleontol. 141: 23-30

Thomsen H. A., Østergaard J. B. and Hansen L. E. (1991) Heteromorphic life histories in Arctic coccolithophorids (Prymnesiophyceae). J. Phycol. 27: 634-642

Triantaphyllou M., Karatsolis B., Dimiza M. D., Malinverno E., Cerino F., Psarra S., Jordan R. W. and Young J. R. (2016) Coccolithophore combination coccospheres from the NE Mediterranean Sea: new evidence and taxonomic revisions. Micropaleontology 61: 457-472

Turland N. J., Wiersema J. H., Barrie F. R., Greuter W., Hawksworth D. L., Herendeen P. S., Knapp S., Kusber W.-H., Li D.-Z., Marhold K., May T. W., McNeill J., Monro A. M., Prado J., Price M. J. and Smith G. F. (2018) International Code of Nomenclature for algae, fungi, and plants (Shenzhen Code) adopted by the Nineteenth International Botanical Congress Shenzhen, China, July 2017. Regnum Vegetabile, 159, Koeltz Botanical Books, Glashütten

Winter A. and Siesser W. G. (1994) Atlas of living coccolithophores, in Coccolithophores (Eds. Winter A. and Siesser W. G.). Cambridge University Press, Cambridge, 107-159

Young J. R. and Bown P. R. (1997) Cenozoic calcareous nannoplankton classification. J. Nannoplankt. Res. 19: 36-47

Young J. R. and Geisen M. (2002) Xenospheres - associations of coccoliths resembling coccospheres. J. Nannoplankton Res. 24 (1): $27-35$

Young J. R., Bergen J. A., Bown P. R., Burnett J. A., Fiorentino A., Jordan R. W., Kleijne A., van Niel B. E., Romein A. J. T. and von Salis K. (1997) Guidelines for coccolith and calcareous nannofossil terminology. Palaeontology 40: 875-912

Young J. R., Bown P. R. and Lees J. A. (2020) Nannotax3 Website. International Nannoplankton Association. URL http://www. mikrotax.org/Nannotax3

Young J. R., Davis S. A., Bown P. R. and Mann S. (1999) Coccolith ultrastructure and biomineralisation. J. Struct. Biol. 126: 195-215

Young J. R., Geisen M., Cros L., Kleijne A., Sprengel C., Probert I. and Østergaard J. (2003) A guide to extant coccolithophore taxonomy. J. Nannoplankt. Res. Spec. Iss. 1: 1-125

Young J. R., Geisen M. and Probert I. (2005) A review of selected aspects of coccolithophore biology with implications for paleobiodiversity estimation. Micropaleontology 51: 267-288

Young J. R., Hagino K. and Poulton A. (2014) Gladiolithus adeyi sp. nov.: a new deep photic coccolithophore species and new molecular genetic and crystallographic observations on Gladiolithus flabellatus. J. Nannoplankt. Res. 34: 61-68

Received on $6^{\text {th }}$ May, 2020; revised on $12^{\text {th }}$ October, 2020; accepted on $22^{\text {nd }}$ October, 2020 